\title{
Nebraska Innovation Studio: A University-Based Makerspace
}

\author{
Shane Farritor, David and Nancy Lederer Professor, Mechanical and \\ Materials Engineering, University of Nebraska
}

7 The University of Nebraska-Lincoln is creating a new makerspace called Nebraska Innovation Studio. Makerspaces are a growing trend across the world and some precedent for University makerspaces exists. A makerspace (sometimes referred to as a Fab Lab, Hobby Shop, or Hacker Space) is a community-oriented physical space where students and other members can build and create. The focus of a makerspace is on creativity, interdisciplinary collaboration, entrepreneurship, and education.

Students from across campus and all community members will be allowed to join the Nebraska Innovation Studio and build their own original projects. $\mathrm{Ne}$ braska Innovation Studio is a both a physical space and a community. The physical space contains specialized tools and equipment (3D printers, laser cutters, computer controlled embroidery machines, machining centers, etc.) along with collaboration space that will allow students to create projects that they are passionate about. The community will provide specialized classes that will enable the students to physically realize their own innovations. These non-degree classes will expand and improve the student's education by allowing them to learn by doing. This experiential education will better show our students that the world is out there to be engaged and shaped.

UNL is creating Nebraska Innovation Studio for several reasons:
- It will strongly contribute to the dynamic multi-disciplinary innovative culture that is a goal of UNL.

- It will allow for innovative experiential student learning. Disciplines from Electrical Engineering to Art to Fashion will teach non-credit courses on how to build things. The space and courses will be designed to encourage collaboration and mixing.

- It will foster entrepreneurship. There are multiple examples of new products created in makerspaces across the United States.

- It will be an attractive facility to encourage interactions between the University and the private sector. It will house expertise and equipment to quickly make prototypes to support the "fail fast and learn" model of innovation.

\section{What is a Makerspace?}

The Recreational Center Analogy

Current Campus Recreational (Cam-

pus Rec) facilities are a good analogy to describe a makerspace. Campus Rec is to 
fitness what the makerspace is to creativity. Students can join Campus Rec and gain access to specialized equipment (e.g. weight room, gym, pool), collaborate with students with similar interests (e.g. pickup basketball), and take non-degree classes (spinning classes, rock climbing classes). All of this is focused on enhancing the student's fitness. Students are not required to participate, they only come to Campus Rec to pursue their passions and do things they love. They go to Campus Rec to improve themselves. In the same way, students will join Nebraska Innovation Studio to gain access to specialized equipment, collaborate with students of similar creative interests, and take nondegree classes.

The Campus Rec system also organizes activities across campus to encourage fitness. It creates programs for employees to walk over the lunch hour or to lose weight, and organizes Intermural sports. Nebraska Innovation Studio will organize activities to encourage creativity, and can serve the same role with invention competitions and creativity seminars.

What will the makerspace look like?

The interior design and layout of the makerspace will be important to foster collaboration and innovation. An oversimplified layout is described here to help explain the makerspace.

The core of the makerspace is an assembly/integration and collaboration space. This is an area where members will gather to put their projects together and in doing so will have the opportunity to interact. Various rooms can then be placed off the main collaboration area for specialized equipment. This arrangement will encourage interactions as members move from room to room.

The specialized rooms will include space for digital fabrication equipment such as 3D printers, laser cutters, water jet cutters, 3D scanners. A computer area will be provided for CAD programming and interaction with the digital fabrication equipment. Other rooms will include equipment for fabric fabrication such as CNC embroidery. Traditional metal and woodworking machinery will also be included. Other areas including a digital classroom and meeting areas will be needed to support the Makerspace.

\section{Why a makerspace?}

There are several important reasons why a world class makerspace is being built at UNL.

\section{The Makerspace Creates Culture}

The first reason to build Nebraska Innovation Studio is that it will help build a culture of innovation. The makerspace will attract students and their energy is the most important ingredient of an innovative university. The students will come to Nebraska Innovation Studio by their choice and to follow their passions. Students can then interact with faculty and community members in a casual environment where common interests are shared.

It is expected that the Nebraska Innovation Studio will spawn other aspects of creative culture. For example, a maker's club has been formed with regular meetings and an annual "Maker's Fair" where members can highlight their latest creation. Studio members then generally subdivide into specialty groups (bike nuts, furniture makers, fashion designers) to further pursue their common interests. 
It is strongly believed that there is a latent demand among many, many UNL students for this opportunity to express their creativity and build things. $\mathrm{Ne}-$ braska students are hands-on problem solvers by our DNA and this makerspace will help develop this tremendous untapped potential.

The Makerspace Will Foster (Student) Entrepreneurship

One of the incredibly beneficial side effects of maker culture is that it is an incubator for entrepreneurship and this entrepreneurship will be built around students. It is believed that UNL students represent a huge untapped potential for new businesses and innovation. The maker community and the facility itself in partnership with other efforts at NUTech Ventures and Nebraska Innovation Campus (NIC) will mine this tremendous potential.

Maker culture is full of successful entrepreneurship stories. For example, the Square card reader (www. squareup. com), that allows you to swipe credit cards with your cell phone, was first built in a community makerspace in San Francisco. Access to the makerspace allowed the founders to build a functional prototype they could then use in demonstrations to venture capital groups. This greatly helped them raise funds and got them started building a multi-milliondollar company that simplifies many lives each day. This invention itself can be a great benefit to all other small businesses further enabling entrepreneurship.

Several smaller scale successes are also common. The MIT Hobby Shop (an existing makerspace) is a constant hotbed of startup prototyping. Just to name a few examples, an undergraduate photography major built her own large format cameras there. She then invented a multicolor LED-based ring flash for specialized photography that is controlled by an embedded microcomputer. This ring flash allows the photographer to dial in the appropriate color for the flash for every picture. She now sells a number of these niche devices through an online business.

A second Hobby Shop startup company was created by a graduate student studying acoustics. This student invented a "speaker dome" that allows museum visitors to stand in front of an exhibit and listen to information about the exhibit without others in the museum being disturbed by the noise. These can be found in several museums around Nebraska. These are simply anecdotal examples of makerspace inspired entrepreneurship.

The Makerspace Will Support a

Business Accelerator

Nebraska Innovation Studio will support a business accelerator that will focus on hardware-based startup companies. The makerspace will be a major benefit for companies in the accelerator because it will allow them to quickly prototype their products. The proximity of the accelerator and the makerspace will increase the quality of companies that apply for the accelerator, potentially attracting companies to Nebraska. As stated before, the makerspace would act as a hub for innovation and creativity by bringing together people from the business accelerator, UNL faculty, students, and staff, and local business.

Successful startup companies often constantly iterate on prototype designs of their products, as suggested by new 
methods of innovation such as Steve Blank's Lean Launch Pad (LLP). For example, an innovative start-up company such as Dyson created over 1,000 prototypes before it created the vacuum cleaner it took to market. Without the makerspace, the process of design iteration can take days or weeks when 3rd party vendors are used for fabrication. Having prototyping capabilities in-house (i.e. in the makerspace), will allow entrepreneurs to turn what can take days into hours, speeding the process and allowing startups to achieve more in less time. This quick design-iterate-feedback cycle has sociological benefits for the startup by allowing it to:

- achieve more and demonstrate more,

- build momentum and give them more control

- create a more positive and enjoyable experience

- reach a marketable product quicker

Overall, the makerspace when combined with a business accelerator will produce more investable companies, with an increased probability of success.

New Skills Are Required for the Quickly Changing World

Cross-Disciplinary Skills Are Now Required

Another important reason to create a UNL student makerspace is that new skills are required for a changing world. This will mean that we need to change the way we educate our students. Skills that used to be valuable are either being automated or can be done more cheaply in other countries. For example, stress analysis used to be a valuable skill for a mechanical engineer. Today, stress analysis is either performed with a software program or is uploaded to an India-based website and a report is emailed back in a few days. Or, legalzoom.com now does many functions attorneys used to charge significant hourly rates to accomplish. What will be valued in the coming economy will be skills like creativity and unique cross-discipline skills such as:

- A fashion designer that knows how to laser cut molds for a production run of 50-100 dresses

- An electrical engineer who can 3D print a custom circuit board enclosure overnight because she doesn't need to coordinate with 3 other departments to get this done.

- An artist who can use an Arduino microprocessor to control an installation piece based on the position of the person observing the work

Nebraska Innovation Studio will produce these kinds of students with cross-disciplinary skills.

Hands-on courses will be taught at the makerspace. For example, the Mechanical Engineering Department might teach a freshman course there like "How to build (almost) anything" for their own students and/or for students from fashion design. However, it is expected that most courses will be taught by makers for makers. For example, a computer science student might waive his membership fee by offering a course like "Introduction to Programming the Arduino Microcontroller" in the evenings.

Again, the makerspace is NOT a traditional machine shop where you pay someone else to build your design. The makerspace is where YOU LEARN by creating your own design and by collaborating with and learning from your peers. 
It is strongly believed that there is a latent demand among many, many UNL students for this opportunity to express their creativity and build things. Almost all makerspaces that are built are almost instantly oversubscribed.

The makerspace will also host an online forum where students can post about their designs and activities. This will help build a community and collaboration where others can build on the designs and best practices of their peers.

Customization is Now Free

The world of product design and manufacturing are dramatically changing with the advent of new digital manufacturing technologies. The result of these digital technologies is that customization is now free.

The twentieth century of manufacturing was about the assembly line and increased access to goods through producing large numbers of identical units at the lowest possible cost (e.g. you can have any color Model T as long as it is black). Cheap labor, low regulation and little concern about the environment favor other countries in manufacturing ten million identical units at minimal cost. However, new technology such as 3D printing allow for customization and automation of manufacturing and open new niche markets that are not realistic for the assembly line model of manufacturing. Many believe these new technologies will lead to a new world of "desktop manufacturing" and "democratized manufacturing" where anyone can make a small number of extremely custom products. In this new model students from all disciplines will need to know how to create products that are specifically customized to individual needs.
New technologies such as 3D printing, and other desktop manufacturing technologies, are analogous to the 2D desktop printing technology that has become common over the past 30 years. Current 3D printers are crude and limited like old dot matrix printers of the early 80's. However, today, we all have our own $\$ 75$ ink jet printer that can create top quality photographs or print our airline tickets with a custom bar code. Future 3D printers will allow us to "print" our own products at our desktop just like we print our own family photos today.

Imagine the future of 3D printing and manufacturing. Today, if you want to buy your child some doll house furniture, you can go to a place like Walmart where there are a few choices of mass produced products. In the future, you might instead download some designs from a hobbyist furniture designer in Sweden, add your child's name to the product, and change the colors so they match the furniture in your own home and then 3D print the doll house furniture from your desktop. This desktop manufacturing allows for total customization (one size fits one) design of products. There is no cost to added complexity (adding your child's name) or customization (changing the color of the furniture). This model will fundamentally change the skills that are needed in the new marketplace (in all disciplines from engineering to furniture designers).

Nebraska Innovation Studio will introduce our students from all disciplines to this new model of customized and niche design and fabrication.

Experiential Learning at the Makerspace (Mind and Hand)

Another way the makerspace will enhance the education of UNL students is 
that it will provide experiential learning. Students will do as a way to learn. It is in the experience of trying to build that much of their education will reside. They will be better prepared to enter the workforce because they have learned important lessons that can only be taught thorough doing.

The lessons learned by doing are differently into a student's brain because of the difficulty they presented and the physical actions required to solve the problems. This is different than missing five points on the forth problem of third exam in a course.

Also, lessons are learned that are generally not taught in class. Students will learn about real-world problems such as shipping delays or how to clamp a part while it is being machined. These lessons will again better prepare them to enter the workforce.

\section{Summary}

The University of Nebraska is creating a makerspace called Nebraska Innovation Studio. The makerspace is a physical space full of equipment that will allow students to build projects and explore their creativity. The space will help build a creative culture that will lead to innovation. Nebraska Innovation Studio will foster a different kind of learning as student involvement will be from intrinsic motivation. The makerspace will help foster entrepreneurship and will encourage cross-disciplinary collaboration. This effort is just beginning at UNL, please look back to check on our progress. 